\title{
Effects of Different Light Spectra on the Oocyte Maturation in Grass Puffer Takifugu niphobles
}

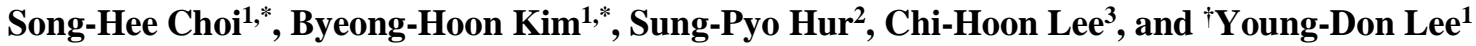 \\ ${ }^{1}$ Marine Science Institute, Jeju National University, Jeju 63333, Korea \\ ${ }^{2}$ Jeju International Marine Science Research \& Logistics Center, Korea Institute of Ocean Science \& Technology, \\ Јеји 63349, Korea \\ ${ }^{3}$ CR Co., Ltd., Jeju 63333, Korea
}

\begin{abstract}
In order to examine the effects of four different light spectra (white, red, green, and blue) on the oocyte maturation, the change of reproductive parameters, via brain-pituitary-gonad (BPG) axis in grass puffer, were investigated. After exposure four different light spectra for 7 weeks, the abundance of gonadotropin-releasing hormone $(G n R H)$ mRNA which is a type of seabream $(s b G n R H)$ and two different subunit of gonadotropin hormones mRNAs, follicle-stimulating hormone $\left(f_{s} h \beta\right)$ mRNA and luteinizing hormone $(\operatorname{lh} \beta)$ mRNA, were analyzed in the brain and pituitary. Histological analysis showed that the mature oocyte ratio in the green spectrum was higher than other light spectra-exposed groups. Gonadosomatic index (GSI) and oocyte developmental stage were also investigated in the gonad based on histological observations. GSI value with the presence of yolk stage oocytes was significantly increased in the green spectrum-exposed group when compared to that of the other light-exposed groups (white, red, and blue) $(p<0.05)$. The abundances of $s b G n R H$ mRNA and $f s h \beta$ mRNA in the green spectrum-exposed group were also significant higher than those of the other light spectra-exposed groups $(p<0.05)$. These results indicate that the maturation of oocyte in grass puffer can be accelerated by exposure to the spectrum of green. To better understand the molecular mechanism for the maturation of oocyte in grass puffer, further study examining the relationship between oocyte development and its related genes is required.
\end{abstract}

Key words : Light spectra, Oocyte maturation, Gonad development, Reproduction-related genes, Grass puffer

\section{INTRODUCTION}

Fish reproduction and light spectra are generally influenced by various environmental factors such as water temperature and light (photoperiod, light spectra and light intensity), tide rhythm and lunar cycle (Jonsson, 1991; Clarke et al., 1999; Takemura et al., 2010; Tielmann et al., 2017).

In recent years, studies on the effects of light conditions on fish physiology such as reproduction, nutrition and stress have been reported (Adams \& Thorpe, 1989; Boeuf \& Le Bail, 1999; Karakatsouli et al., 2008). The continuous photoperiod treatment increases rainbow trout $(\mathrm{On}$ corhynchus mykiss) growth and feed efficiency (Taylor et al., 2006). In the effect of light spectra of sapphire devil (Chrysiptera cyanea), a subtropical fish, the gonadosomatic index (GSI) value is higher in the red light spectra than that in the white light, and ovarian development is induced

\footnotetext{
Manuscript received May 16, 2018, Received in revised form May 29, 2018, Accepted June 4, 2018

${ }^{\dagger}$ Corresponding Author : Young-Don Lee, Marine Science Institute, Jeju National University, Jeju 63333, Korea. Tel: +82-64-782-8922, Fax: +82-64782-8281, E-mail: leemri@jejunu.ac.kr

${ }^{*}$ These authors contributed equally.
}

This is an Open Access article distributed under the terms of the Creative Commons Attribution Non-Commercial License (http:// creative-commons.org/licenses/by-nc/3.0) which permits unrestricted non-commercial use, distribution, and reproduction in any medium, provided the original work is properly cited. 
(Bapary et al., 2011). The red light spectra reduce the stress of yellow perch (Perca flavescens) (Head \& Malison, 2000). The growth rate of rockfish (Sebastes inermis) in the juvenile stage is higher at the green light spectra than that at the natural light spectrum and red light spectrum (Shin et al., 2015).

Most of the currently cultured fish species are fed and managed by controlling brightness using natural light, incandescent light and light emitting diode (LED). However, information on proper light condition management according to fish species has been insufficient. Therefore, it is necessary to have a technology of using adaptive characteristics of the cultured fish species using appropriate light conditions to improve the productivity and reduce stress of the cultured fish species. The purpose of this study was to investigate the light spectra conditions affecting gonad development in grass puffer (Takifugu niphobles). Grass puffer has a spawning ecological characteristic of migrating to a coastal area with low water depth during the spawning period, while it lives in a depth of $20 \mathrm{~m}$ in the non-spawning period (Yamahira, 1996).

This study examined the changes in the expression level of reproduction-related genes (Gonadotropin-releasing hormone, follicle stimulating hormone, luteinizing hormone genes) and the development pattern of gamete in gonad according to light spectra in grass puffer during the spawning season.

\section{MATERIALS AND METHODS}

\section{Experimental fish}

Grass puffer was caught by a net in Jocheon, Jeju Island and then reared in a fish tank at the Jeju National University Marine Science Research Institute. It domesticated at natural water temperature in the natural photoperiod before using experiment. Feed (Daehan Co., MP3, Busan, Korea) was supplied twice a day.

\section{Experimental conditions}

Grass puffers were raised in the indoor water tank under the condition of natural water temperature $\left(15.5-17.7^{\circ} \mathrm{C}\right)$ in the running water system. It was divided into white (control), red $(590 \mathrm{~nm})$, green $(520 \mathrm{~nm})$ and blue $(480 \mathrm{~nm})$ light treatment groups using LED (125 W; Sanver, Korea) light spectra. Grass puffers $(n=160$, body length $=13.1 \pm 0.2$ $\mathrm{cm}$, body weight $=41.1 \pm 1.7 \mathrm{~g}$ ) were randomly divided into 40 fish in each tank. Grass puffers reared at the natural water temperature during the experiment, and the photoperiod was adjusted to the natural photoperiod using a timer. The light intensity of the LED was measured using a digital illumination meter (DX-200, Taiwan). The light intensity was treatments was adjusted 1,200 Lx and controlled by adjusting the distance from approximately $30 \mathrm{~cm}$ between the water surface and the LED. Grass puffers were reared for seven weeks and sampled after it was anesthetized using MS-222 (Sigma, USA) at the end of the experiment. Eight grass puffers were randomly selected for each experimental group for sampling. Ovaries of grass puffer were weighed to calculate GSI and then fixed in Bouin's solution to investigate the gonad developmental stage. To examine the expression of reproduction-related genes, the brains and pituitary glands of grass puffer were collected and stored at $-80^{\circ} \mathrm{C}$ before analysis.

\section{Ovarian developmental stage}

To investigate the effects of light spectra adaptation on the gonad development of grass puffer, grass puffer was reared during seven weeks under the different light spectra conditions, and the ovaries were collected. The ovaries were weighed to calculate GSI, and the ovarian development stage was examined using a histological method. The ovaries were fixed in Bouin's solution and then stored in $70 \%$ ethanol. Ovarian tissues were embedded in paraffin and sectioned in $5 \mu \mathrm{m}$ thickness using microtome. Paraffin sections were stained with Gill's hematoxylin and $0.5 \%$ eosin, and gonad development stage was observed using optical 
microscopy (Olympus, Tokyo, Japan) and cellSens Standard software (Olympus, Tokyo, Japan). The percentage of each oocyte developmental stage was the percentage of oocyte number in each developmental stage to the total oocyte number in gonad cross section. Each oocyte developmental stage were divided to PNS, peri-nucleolus stage; ODS, oil-droplet stage; YS, Yolk stage (YS=PYS (primary yolk stage)+SYS (secondary yolk stage)+TYS (tertiary yolk stage)).

\section{Total RNA extraction and cDNA synthesis}

RiboEx ${ }^{\mathrm{TM}}$ reagent (GeneAll, Seoul, Korea) were added to the brains and pituitary tissues collected from grass puffer, and the samples were completely homogenized using a homogenizer. Total RNA treated with RQ NRaseFree DNase (Promega, Madison, USA). Only the DNasetreated total RNA with 1.7-2.1 ratio of A260/A280 nm was used in the experiment using Nano Vue (GE Healthcare, Ver.1.0.1, London, UK). cDNA was synthesized using PrimeScript 1st strand cDNA synthesis Kit (Takara, Japan) with the template of DNase-treated total RNA $0.5 \mu \mathrm{g}$.

\section{Real time-quantitative PCR}

For the reproduction-related genes of grass puffer according to the light spectra, primers were constructed using the gene information registered in National Center for Biotechnology Information (NCBI, Table 1). Real time-quantitative PCR was performed using $0.2 \mu \mathrm{g}$ of cDNA and the Evagreen premix PCR kit (abm, Canada). Real time-quantitative PCR was conducted using CFX96 ${ }^{\mathrm{TM}}$ Real Time System (BIO-RAD, USA), and the expression of reproduction-related genes was relatively quantitated using $\beta$-actin as an internal control (Table 1).

\section{Statistical analysis}

The results of gene expression through real time-quantitative PCR were presented using mean \pm standard error (SEM). One-way analysis of variance (ANOVA) was per-
Table 1. Primer sets used in real time-quantitative PCR

\begin{tabular}{|c|c|c|}
\hline Primers & Sequence $\left(5^{\prime}-3^{\prime}\right)$ & $\begin{array}{c}\text { GeneBank } \\
\text { Acession No }\end{array}$ \\
\hline $\begin{array}{l}s b G n R H-\mathrm{F} \\
s b G n R H-\mathrm{R}\end{array}$ & $\begin{array}{l}\text { TGTCAGCACTGGTCCTATGG } \\
\text { GGTCCGGCTGTTCAGAATTT }\end{array}$ & AB531127 \\
\hline $\begin{array}{l}\text { chGnRH-F } \\
\text { chGnRH-R }\end{array}$ & $\begin{array}{l}\text { СССТTTCAACCCCTCAGAGAT } \\
\text { GGAGCTCTCTGGTTAAGGCA }\end{array}$ & AB531128 \\
\hline $\begin{array}{l}s a G n R H-\mathrm{F} \\
s a G n R H-\mathrm{R}\end{array}$ & $\begin{array}{l}\text { AGGATGATGGGGACGGGA } \\
\text { СTTCTCTTTGGGTCGAAGCG }\end{array}$ & AB531129 \\
\hline $\begin{array}{l}f \operatorname{sh} \beta-\mathrm{F} \\
f \operatorname{sh} \beta-\mathrm{R}\end{array}$ & $\begin{array}{l}\text { GTAACGGCGACTGGACCTAT } \\
\text { CATGTCCCCATTGAAGCGAC }\end{array}$ & AB543564 \\
\hline $\begin{array}{l}\ln \beta-\mathrm{F} \\
\ln \beta-\mathrm{R}\end{array}$ & $\begin{array}{l}\text { CTGCATCACCAAGGACCCAG } \\
\text { AAGGTGCAGTCGGATGTGTT }\end{array}$ & AB543563 \\
\hline $\begin{array}{l}\beta \text {-actin-F } \\
\beta \text {-actin- } \mathrm{R}\end{array}$ & $\begin{array}{l}\text { GCCATCCTTCCTTGGTATGGA } \\
\text { GTCGTACTCCTGCTTGCTGA }\end{array}$ & EU871643 \\
\hline
\end{tabular}

formed to determine the significance of the measured mean values using least significant difference (LSD).

\section{RESULTS}

\section{Gonad development stage according to light spectra}

GSI of each light spectrum was in the range of 1.9-3.1 at the beginning of the experiment. According to the adaptation of the light spectrum over seven weeks, the GSI value was $1.3-3.2$ at the white spectrum, $2.2-2.9$ at the red spectrum, 2.9-5.3 at the green spectrum, and 1.0-2.5 at the blue spectrum. Thus, the GSI value was significantly different at the green spectrum (Fig. 1, $p<0.05$ ).

The percentage and diameter of oocyte in light treatment groups were investigated by histological analysis. In the green spectrum group, many yolk stage oocytes (YO) with accumulated with yolk granules and some ODS and PNS were distributed. The diameter of YO was about 290-380 $\mu \mathrm{m}$, and the percentage of distribution counting of YO was $26.7 \%$. The diameter of ODS was about $190-270 \mu \mathrm{m}$, and 


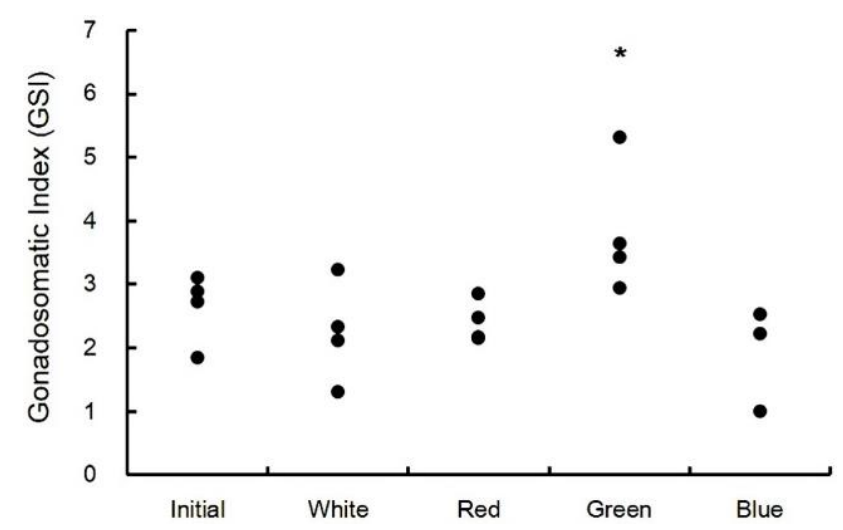

Fig. 1. Changes of gonadosomatic index (GSI) levels in the grass puffer under different light spectra conditions. Asterisk indicate significant difference among the means $(p<0.05)$. Values are mean \pm SEM (Initial $n=4$, white $n=4$, red $n=4$, green $=4$, blue $n=3$ ).

the percentage of distribution counting of ODS was $36.1 \%$. At the white spectrum, the diameter of ODS was 170-250 $\mu \mathrm{m}$, and the percentage of distribution counting of ODS was $42.5 \%$. The diameter of PNS was $30-80 \mu \mathrm{m}$, and the percentage of distribution counting of ODS was $45.7 \%$. At the red spectrum, the diameter of ODS was 160-260 $\mu \mathrm{m}$, and the percentage of distribution counting of ODS was $44.1 \%$. The diameter of PNS was $25-60 \mu \mathrm{m}$, and the percentage of distribution counting of PNS was 39.1\%. At the blue spectrum, the diameter of ODS was 190-250 $\mu \mathrm{m}$, and the percentage of distribution counting of ODS was $46.5 \%$. The diameter of PNS was 30-50 $\mu \mathrm{m}$, and the percentage of distribution counting of PNS was $35.4 \%$ (Fig. 2 and 3).

2. Expression of reproduction-related genes by light spectra

The expression of GnRHs ( $s b G n R H, s a G n R H, c h G n R H)$ mRNA in the brain and gonadotropin hormones $(\mathrm{GtH})$ $(f \operatorname{sh} \beta$ and $\operatorname{lh} \beta$ ) mRNA in the pituitary gland were examined under different light spectra (Fig. 4). The expression of $s b G n R H$ mRNA was $0.1-0.5$ at the beginning of the experiment. According to light spectrum adaptation for seven weeks, it was $0.2-0.5$ at the white spectrum, $0.1-0.7$ at the red spectrum, $0.5-1.5$ at the green spectrum, and $0.3-1.0$ at

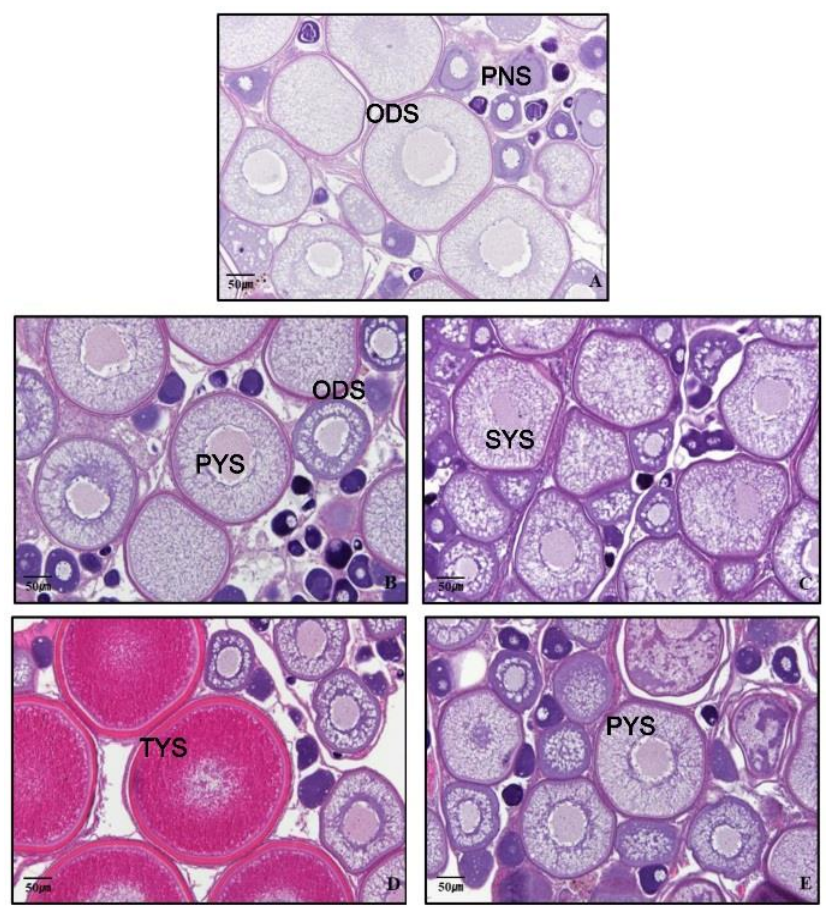

Fig. 2. Photomicrograph of ovarian development phases of grass puffer under different light spectra conditions (A, initial $n=4 ; B$, white $n=4 ; C$, red $n=4$; D, green $n=4 ; E$, blue $n=3$ ). Scale bar indicates 50 $\mu \mathrm{m}$. PNS, peri-nucleolus stage; ODS, oil-droplet stage; PYS, primary yolk stage; SYS, secondary yolk stage; TYS, tertiary yolk stage.

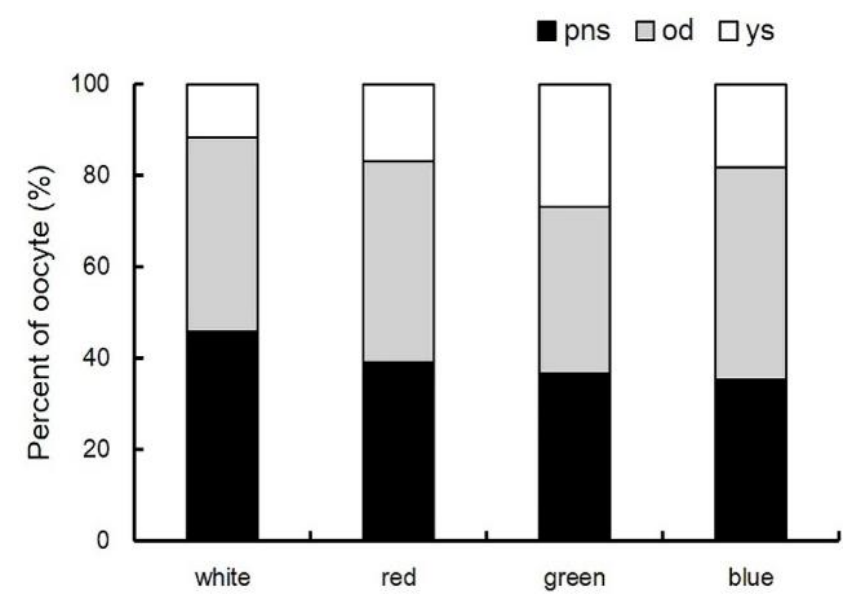

Fig. 3. Percent of oocyte of grass puffer under different light spectra conditions (initial $n=4$, white $n=4$, red $n=4$, green=4, blue $n=3$ ). PNS, peri-nucleolus stage; ODS, oil-droplet stage; YS, Yolk stage (YS= PYS (primary yolk stage)+SYS (secondary yolk stage)+TYS (tertiary yolk stage)). 
the blue spectrum (Fig. 4A). The expression of $s a G n R H$ mRNA was $0.2-1.0$ at the beginning of the experiment. According to light spectrum adaptation for seven weeks, it was $0.4-1.2$ at the white spectrum, $0.7-1.1$ at the red spectrum, $0.5-1.1$ at the green spectrum, and $0.2-1.2$ at the blue spectrum (Fig. 4B). The expression of $c h G n R H$ mRNA was $0.1-0.3$ at the beginning of the experiment. According
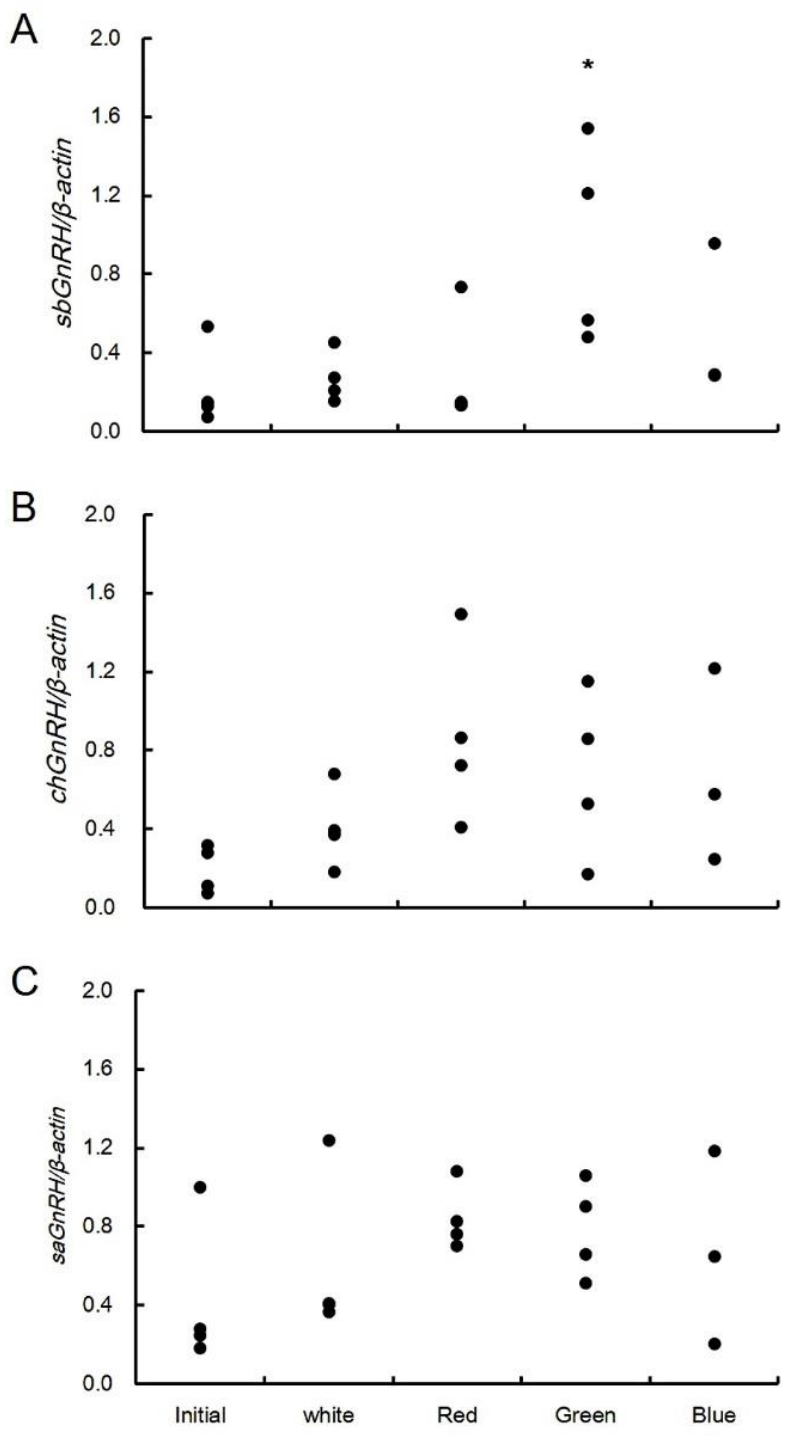

Fig. 4. Expression changes of $s b G n R H$, chGnRH and saGnRH mRNA in the grass puffer brain under different light spectra conditions. Asterisk indicate significant difference among the means $(p<$ 0.05 ). Values are mean $\pm \operatorname{SEM}$ (initial $\mathrm{n}=4$, white $\mathrm{n}=$ 4 , red $n=4$, green $=4$, blue $n=3$ ). to light spectrum adaptation for seven weeks, it was 0.2 0.7 at the white spectrum, $0.4-1.5$ at the red spectrum, $0.2-$ 1.2 at the green spectrum, and $0.2-1.2$ at the blue spectrum (Fig. 4C). Analysis of the average value of expression indicated that $s b G n R H$ mRNA had a significantly higher expression at the green spectrum than at the other spectra $(p<0.05)$. The expression of $c h G n R H$ mRNA and $s a G n R H$ mRNA showed a similar trend, and there was no significant difference according to light spectra.

The expression of $f s h \beta$ mRNA in the pituitary gland was $0.2-0.6$ at the beginning of the experiment. According to light spectrum adaptation for seven weeks, it was $0.1-0.4$ at the white spectrum, 0.1-0.9 at the red spectrum, 0.5-2.6 at the green spectrum, and $0.1-0.3$ at the blue spectrum (Fig. 5A). The expression of $\operatorname{lh} \beta$ mRNA was $0.001-0.039$ at the beginning of the experiment. According to light
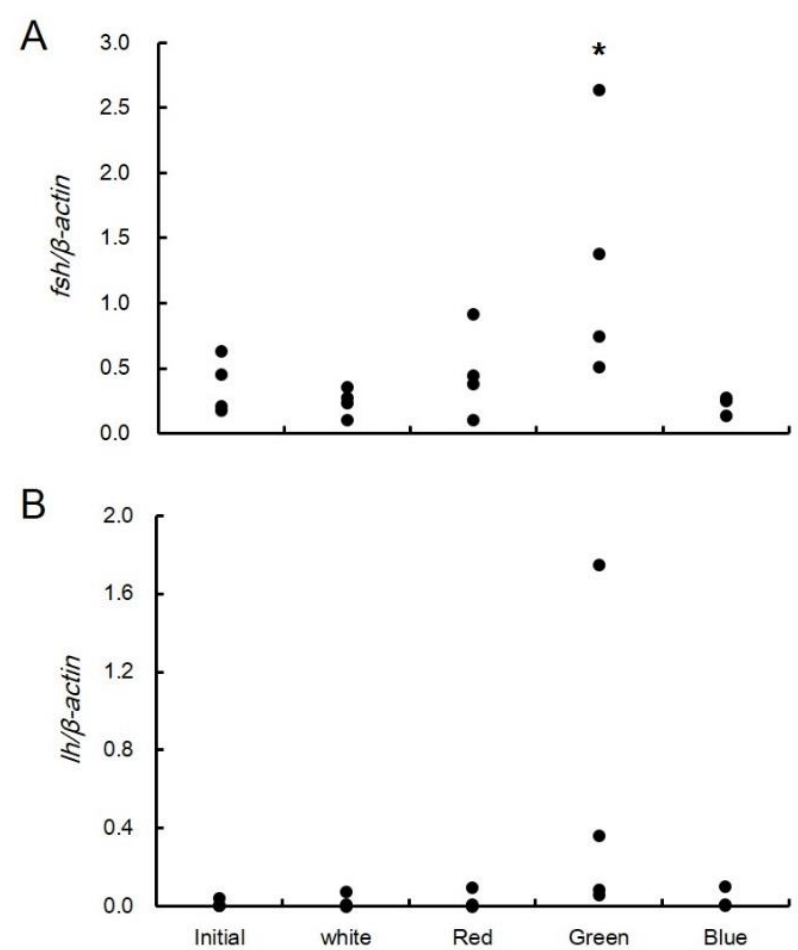

Fig. 5. Expression changes of $f \operatorname{sh} \beta$ and $\operatorname{lh} \beta$ mRNA in the grass puffer brain under different light spectra conditions. Asterisk indicate significant difference among the means $(p<0.05)$. Values are mean \pm SEM (initial $n=4$, white $n=4$, red $n=4$, green $=4$, blue $n=3$ ). 
spectrum adaptation for seven weeks, it was 0.0004-0.07 at the white spectrum, 0.0004-0.09 at the red spectrum, $0.06-1.7$ at the green spectrum, and $0.002-0.1$ at the blue spectrum (Fig. 5B). Analysis of the average value of expression indicated that $f s h$ mRNA had a significantly higher expression at the green spectrum than at the other spectra. However, the expression of $l h$ mRNA was not significantly different according to experimental conditions.

\section{DISCUSSION}

Stimulation of external environmental factors is involved in gonad development and spawning by activation of the brain-pituitary-gonad (BPG) axis. This stimulation is transmitted to the brain and promotes synthesis and secretion of gonadotropin-releasing hormone $(\mathrm{GnRH})$ in the hypothalamus. GnRH is an important factor controlling the BPG axis. GnRH secreted from the hypothalamus is transmitted to the pituitary gland and promotes secretion of luteinzing hormone (LH) and follicle stimulating hormone (FSH), which are gonadotropin hormones $(\mathrm{GtH})$.

The spawning season of grass puffer belonging to the Tetraodontidae in Korea is from late May to early July and is known to be related to lunar phase, high tide, and spring tide (Oh et al., 2000). The main habitat is an intertidal zone within $20 \mathrm{~m}$ depth, and grass puffer has an ecological characteristic of entering the coast in the spawning season (Yamahira, 1996).

Recently, several studies were investigated on the effect of light spectrum on reproductive and growth performance (Shin et al, 2014; Kim et al., 2016). According to studies on gold fish (Carassius auratus), the gene expression of $\mathrm{GnRH}$ and GtH as well as Kisspeptin (known to be a major regulator of reproduction and puberty initiation) increased at the green spectrum compared to that at the red spectrum. In terms of ovary development stage, the ovary was more mature at the green spectrum (Shin et al., 2014). This study investigated the effects of light spectra on the gonad development in grass puffer using histological and genetic methods. In the present study, we observed higher GSI, expression of $G n R H, f s h \beta$, and $l h$ mRNA in grass puffer at the green spectrum than that at other spectra. The ovary was more mature at the green spectrum. Similar to the action of green spectrum in gold fish to induce sexual maturation, it is considered that the green spectrum induces sexual maturation in grass puffer.

When goldfish were grown under the green and red spectrum conditions, the expression of $f_{s h} \beta$ and $\ln \beta$ mRNA in the pituitary gland was significantly increased at the green spectrum (Song et al., 2016). In addition, the expression of vertebrate ancient-long opsin (val-opsin) mRNA in the hypothalamus was increased at the green spectrum, and artificial GtH administration induced the expression of valosin mRNA. VAL-opsin is a type of membrane protein that constitutes photoreceptor cells. It reacts specifically at the green spectrum and exists in the deep brain and in the horizontal cells of the retina (Kojima et al., 2000). Therefore, it is thought that the green spectrum caused the activity of VAL- opsin, increased the secretion of GtH, and induced puberty of goldfish. However, there have been insufficient studies on photoreceptors, and the light spectrum leading to puberty is not constant for each fish. Therefore, it is necessary to carry out studies on photoreceptors in grass puffer.

According to a study on Atlantic salmon (Salmo salar), the ability of pineal gland to inhibit the melatonin secretion was decreased at the red spectrum than that at the blue and green spectra (Vera et al., 2010). Under the same condition, each light spectrum condition did not affect the melatonin secretion in Atlantic cod (Gadus morhua) and European sea bass (Dicentrarchus labrax). In sapphire devil, the blue spectrum suppressed the secretion of melatonin more than the green and red spectra (Takeuchi et al., 2014).

These results suggest that light spectra affecting sexual maturation are different from species to species, thus having species-specific characteristics. In this study, ovary 
development was induced at the green spectrum in grass puffer. This result may be highly correlated with the grass puffer's spawning ecological characteristic of entering the coast in the spawning season. The results of this study will be helpful to present an environment-friendly farming management technology according to farmed species.

\section{ACKNOWLEDGEMENTS}

This research was supported by the 2017 scientific promotion program funded by Jeju National University.

\section{REFERENCES}

Adams CE, Thorpe JE (1989) Photoperiod and temperature effects on early development and reproductive investment in Atlantic salmon (Salmo salar L.). Aquaculture 79:403-409.

Bapary MAJ, Amin MN, Takeuchi Y, Takemura A (2011) The stimulatory effects of long wavelengths of light on the ovarian development in the tropical damselfish, Chrysiptera cyanea. Aquaculture 314:188-192.

Boeuf G, Le Bail PY (1999) Does light have an influence on fish growth?. Aquaculture 177:129-152.

Clarke A, Johnston NM (1999) Scaling of metabolic rate with body mass and temperature in teleost fish. J Anim Ecol 68:893-905.

Head AB, Malison JA (2000) Effects of lighting spectrum and disturbance level on the growth and stress responses of yellow perch Perca flavescens. J World Aquacult Soc 31:73-80.

Jonsson N (1991) Influence of water flow, water temperature and light on fish migration in rivers. Nord J Freshw Res 66:20-35.

Karakatsouli N, Papoutsoglou SE, Panopoulos G, Papoutsoglou ES, Chadio S, Kalogiannis D (2008) Effects of light spectrum on growth and stress response of rainbow trout Oncorhynchus mykiss reared under recircu- lating system conditions. Aquacult Eng 38:36-42.

Kim BH, Hur SP, Hur SW, Lee CH, Lee YD (2016) Relevance of light spectra to growth of the rearing tiger puffer Takifugu rubripes. Dev Reprod 20:23-29.

Kojima D, Mano H, Fukuda Y (2000) Vertebrate ancientlong opsin: A green-sensitive photoreceptive molecule present in zebrafish deep brain and retinal horizontal cells. J Neurosci 20:2845-2851.

Oh SH, Han KH, Kim YM, Joung HH, Shin SS, Kim YU (2000) Spawning behavior and early life history of Grass Puffer, Takifugu niphobles (Jordan et Snyder) (Teleostei: Tetraodontidae). Kor J Ichthyol 12:236-243.

Shin HS, Habibi HR, Choi CY (2014) The environmental regulation of maturation in goldfish, Carassius auratus: Effects of various LED light spectra. Comp Biochem Physiol A Mol Integr Physiol 168:17-24.

Shin HO, Hoe MA, Heo G (2015) The effect of LED light wavelength on the growth of fingerling Sebastes inermis. J Kor Soc Fish Technol 51:179-187.

Song JA, Kim NN, Choi YJ, Choi JY, Kim BS, Choi CY (2016) Effects of light-emitting diode spectra on the vertebrate ancient long opsin and gonadotropin hormone in the goldfish Carassius auratus. Biochem Biophys Res Commu 476:541-545.

Takemura A, Rahman MS, Park YJ (2010) External and internal controls of lunar-related reproductive rhythms in fishes. J Fish biol 76:7-26.

Taylor JF, North BP, Porter MJR, Bromage NR, Migaud H (2006) Photoperiod can be used to enhance growth and improve feeding efficiency in farmed rainbow trout, Oncorhynchus mykiss. Aquaculture 256:216-234.

Takeuchi Y, Imamura S, Sawada Y, Hur SP, Takemura A (2014) Effects of different colors of light on melatonin suppression and expression analysis of Aanat1 and melanopsin in the eye of a tropical damselfish. Gen Comp Endocr 204:158-165.

Tielmann M, Schul C, Meyer S (2017) The effect of light intensity on performance of larval pike-perch (Sander 
lucioperca). Aquacult Eng 77:61-71.

Vera LM, Davie A, Taylor JF, Migaud H (2010) Differential light intensity and spectral sensitivities of Atlantic salmon, European sea bass and Atlantic cod pineal glands ex vivo. Gen Comp Endocrinol 165:25-33.

Yamahira K (1996) The role of intertidal egg deposition on survival of the puffer, Takifugu niphobles (Jordan et Snyder), embryos. J Exp Mar Biol Ecol 198:291-306. 